\title{
Analisis Faktor-Faktor Yang Mempengaruhi Permintaan Konsumen Rumah Tangga Terhadap Minyak Goreng Curah Di Gampong Lamtimpeung Kecamatan Darussalam Aceh Besar
}

\section{(Analysis Of Factors Affecting Household Consumer's Demand for Bulk Cooking Oil in Lamtimpeung Village of Darussalam Aceh Besar )}

\author{
Dede Ery Astuty ${ }^{1}$, Mustafa Usman ${ }^{1}$, Teuku Fauzi ${ }^{1 *}$ \\ ${ }^{1}$ Program Studi Agribisnis, Fakultas Pertanian, Universitas Syiah Kuala
}

\begin{abstract}
Abstrak. Permintaan adalah keinginan konsumen membeli suatu barang pada berbagai tingkat harga selama periode waktu tertentu. Penelitian ini bertujuan untuk menganalisis faktor-faktor yang mempengaruhi permintaan konsumen rumah tangga terhadap minyak goreng curah dan menganalisis elastisitas permintaan konsumen rumah tangga terhadap minyak goreng curah di gampong Lamtimpeung kecamatan Darussalam, Aceh Besar. Penentuan lokasi penelitian dilakukan secara purposive, pengambilan sampel penelitian ini dilakukan secara proportionate stratified random sampling, dengan jumlah sampel sebanyak 51 konsumen rumah tangga yang ditentukan menggunakan rumus Slovin. Data yang digunakan adalah data primer dari konsumen rumah tangga di gampong Lamtimpeung kecamatan Darussalam Aceh Besar dengan menggunakan kuisioner dan data sekunder didapatkan dari Dinas Pangan Provinsi Aceh. Penelitian ini menggunakan analisis regresi linier berganda yang ditransformasikan kedalam logaritma natural. Hasil analisis regresi linier berganda menunjukkan bahwa faktor-faktor yang mempengaruhi permintaan minyak goreng curah di gampong Lamtimpeung kecamatan Darussalam Aceh Besar secara signifikan adalah harga minyak goreng kemasan dan jumlah anggota keluarga, sedangkan faktor-faktor yang tidak berpengaruh secara signifikan adalah harga minyak goreng curah, harga ikan tongkol, jumlah pendapatan serta tingkat pendidikan. Elastisitas harga mennunjukkan bahwa minyak goreng curah adalah barang inelastis dengan minyak goreng kemasan sebagai barang subtitusi sedangkan ikan tongkol merupakan barang komplementer dan berdasarkan elastisitas pendapatan minyak goreng curah merupakan barang inferior.
\end{abstract}

Kata kunci: Permintaan, Minyak Goreng Curah, Elastisitas.

Abstract. Demand is the desire of consumers to buy an item at various price levels over a period of time. The aims of this research is to analyze the factors that affect household consumer's demand for bulk cooking oil and for analyze the elasticity of household costumer's demand for bulk cooking oil in Lamtimpeung village of Darussalam, Aceh Besar. The location of this research is determind by using purposive method, sampling of this research is determind by using proportionate stratified random sampling with a total sample of 51 household consumers determind by using the Slovin formula. The primary data are collected from household consumers in Lamtimpeung village of Darussalam Aceh Besar, through direct interview by using quisioner and the secondary data are obtained from Dinas Pangan Provinsi Aceh. This research uses multiple linier regression analysis which are transformed into natural logarithms. The result of multiple linier regression analysis showsif the factors that influence the demand for bulk cooking oil in Lamtimpeung village of Darussalam Aceh Besar significantly are the price of package cooking oil and family members, while the factors not influence significantly are the price of bulk cooking oil, price of tuna, the amount of income and the level of education. Price elasticity indicates that bulk cooking oil is an inelastic item with packaging cooking oil as subtitution goods while tuna is a complementary goods and income elasticity indicates that bulk cooking oil is inferior goods.

Keywords: Demand, bulk cooking oil, elasticity. 


\section{PENDAHULUAN}

Minyak goreng adalah salah satu bahan yang termasuk dalam lemak, baik yang berasal dari lemak tumbuhan maupun dari lemak hewan atau dibuat secara sintetik (Ketaren, 2008). Minyak goreng sendiri merupakan salah satu dari sembilan bahan pokok yang dikonsumsi masyarakat di Indonesia, baik yang berada di pedesaan maupun di perkotaan. Sebagaimana yang dinyatakan oleh Martianto (2005) bahwa minyak goreng merupakan komoditas kedua setelah beras yang dikonsumsi oleh lebih dari $90 \%$ penduduk di Indonesia. Penggunaan minyak goreng sendiri berfungsi sebagai medium penghantar panas, menambah rasa gurih, dan menambah nilai gizi serta kalori dalam makanan.

Minyak goreng yang dikonsumsi masyarakat di Indonesia sebagian besar adalah minyak goreng nabati dengan bahan baku kelapa sawit (minyak goreng sawit), karena minyak goreng jenis ini cukup ideal dari segi harga dan relatif stabil dari segi ketersediaannya. Minyak goreng dengan bahan baku kelapa sawit di pasaran terbagi dalam dua segmen, yaitu minyak goreng curah dan minyak goreng kemasan dengan merk/label tertentu.

Minyak goreng curah dan minyak goreng kemasan merupakan minyak goreng yang sama-sama hasil dari proses industri, namun memiliki perbedaan dari segi kualitas. Dimana minyak goreng curah yang hanya mengalami 1 kali proses pemurnian saja, memiliki kualitas yang lebih rendah jika dibandingkan dengan minyak goreng kemasan yang melaalui 3 sampai 4 kali proses pemurnian.

Adapun proses pemurnian minyak goreng meliputi: (1) degumming merupakan proses pemisahan getah atau lendir berupa fosfatida, air, protein, residu dan karbohidrat tanpa mengurangi jumlah asam lemak bebas; (2) netralisasi merupakan proses pemisahan asam lemak bebas dari minyak dengan cara mereaksikannya dengan basa atau pereaksi lainnya sehinggamembentuk sabun; (3) pemucatan merupakan proses penghilangan zat-zat warna yang tidak disukai dalam minyak; dan (4) deodorisasi merupakan proses penghilangan bau dan rasa yang tidak enak dalam minyak (Ketaren, 1986).

Dilihat dari aspek kebersihan produk, minyak goreng kemasan lebih baik dari minyak goreng curah. Beberapa kelebihan dan kekurangan minyak goreng curah dan minyak goreng kemasan yang dapat dilihat pada tabel dibawah ini:

Tabel 1. Kelebihan dan Kekurangan Minyak Goreng Curah dan Minyak Goreng Kemasan

\begin{tabular}{|c|c|c|}
\hline & Kelebihan & Kekurangan \\
\hline Minyak Goreng Curah & $\begin{array}{l}\text { 1. Harga relatif lebih } \\
\text { murah }\end{array}$ & $\begin{array}{l}\text { 1. Warnanya kuning keruh } \\
\text { 2. Tidak dikemas } \\
\text { 3. Kandungan kadar lemak } \\
\text { dan asam oleat tinggi }\end{array}$ \\
\hline $\begin{array}{l}\text { Minyak } \\
\text { Kemasan }\end{array}$ & $\begin{array}{l}\text { 1. Kebersihandan } \\
\text { kualitas lebih baik } \\
\text { 2. Warnanya jernih } \\
\text { 3. Dikemas dengan } \\
\text { merk tertentu }\end{array}$ & \\
\hline
\end{tabular}

Minyak goreng curah yang hanya mengalami 1 kali proses pemurnian (hanya sampai pada tahap olein saja) masih mengandung minyak fraksi padat, sehingga kandungan kadar lemak dan asam oleat relatif tinggi. Hal ini yang menyebabkan warna minyak goreng curah lebih keruh jika dibandingkan minyak goreng kemasan. Selain itu, minyak goreng curah juga merupakan minyak yang disimpan di tempat terbuka dan dalam bentuk silo atau drum.

Analisis Faktor-Faktor Yang Mempengaruhi Permintaan Konsumen Rumah Tangga Terhadap

Minyak Goreng Curah Di Gampong Lamtimpeung Kecamatan Darussalam Aceh Besar 146

(Dede Ery Astuty, T. Fauzi , Mustafa Usman)

Jurnal Ilmiah Mahasiswa Pertanian Unsyiah, Vol. 3, No. 2, Mei 2018: 145-159 
Selama dalam rantai pendistribusian yang panjang dan luas juga menggunakan sarana angkut tangki. sehingga originalitas minyak goreng curah dari pabrik hingga konsumen juga ndipengaruhi oeh sanitasi lingkungan, seperti peralatan angkut (tangki), bongkar muat (pompa drum), maupun kemasan eceran, lingkungan pasar tradisional yang umumnya tidak begitu bersih dan sarana pendukung transaksi lainnya. Sehingga faktor higienitas minyak goreng curah setelah sampai dikonsumen diragukan.

Konsumsi minyak goreng sawit non industri atau rumah tangga secara nasional saat ini mencapai 4444 juta ton per tahun, dimana 16,35\% konsumsi dalam bentuk minyak goreng kemasan dan 73,65\% daam bentuk minyak goreng curah. Di seluruh dunia saat ini, hanya di Indonesia dan Bangladesh saja yang mayoritas penduduknya masih mengkonsumsi minyak goreng curah, sehingga di Asia Tenggara hanya Indonesia saja yang masih menggunakan minyak goreng curah untuk konsumsi rumah tangga (GIMNI dalam Utami, 2014).

Permintaan terhadap minyak goreng di Indonesia semakin meningkat, seiring dengan makin tumbuh dan berkembangnya perekonomian nasional serta permintaan dari industri pengolahan maupun industri makanan yang semakin tinggi. Hal ini dikarenakan permintaan dari rumah tangga tidak hanya bersumber dari pertumbuhan penduduk tetapi juga dari konsumsi per kapita.

Minyak goreng kemasan dan minyak goreng curah juga memiliki perbedaan dari segi harga. Dimana harga minyak goreng kemasan relatif lebih mahal jika dibandingkan dengan minyak goreng curah. Rata-rata harga minyak goreng kemasan (Bimoli) dan minyak goreng curah (Malinda) dapat diperoleh di Dinas Pangan Provinsi Aceh.

Adapun perbedaan harga minyak goreng kemasan dan minyak goreng curah (tanpa merk) dari keduanya dapat dilihat pada tabel dibawah ini:

Tabel 2. Rata-rata Harga Minyak Goreng Kemasan (Bimoli) dan Minyak Goreng Tanpa Merk (Malinda) 2012-2016 di Kota Banda Aceh

\begin{tabular}{llcc}
\hline No. & Tahun & $\begin{array}{r}\text { Rata-rata Harga Bimoli } \\
(\mathrm{Rp} / \mathrm{kg})\end{array}$ & $\begin{array}{c}\text { Rata-rata Harga Malinda } \\
(\mathrm{Rp} / \mathrm{kg})\end{array}$ \\
\hline 1 & 2012 & 14.069 & 11.251 \\
2 & 2013 & 11.758 & 8.760 \\
3 & 2014 & 12.033 & 9.553 \\
4 & 2015 & 12.208 & 8.653 \\
5 & 2016 & 16.000 & 11.375 \\
& Rata-rata & 13.214 & 9.918 \\
\hline
\end{tabular}

Sumber: Dinas Pangan Provinsi Aceh, 2017

Tabel 2 menunjukkan persentase penurunan dan kenaikan harga minyak goreng kemasan (Bimoli) dan minyak goreng tanpa merek (Malinda) setiap tahun, dari tahun 2013 sampai 2016 berdasarkan tahun sebelumnya. Adapun pada tahun 2013 minyak goreng Bimoli mengalami penurunan harga sebesar $16,43 \%$ dari tahun sebelumnya, sedangkan pada tahun 2014 mengalami kenaikan sebesar 2,3\% dan pada tahun 2015 serta 2016 juga mengalami kenaikan sebesar $1,45 \%$ dan $31,5 \%$.

Selain harga minyak goreng kemasan (Bimoli) minyak goreng tanpa merek (Malinda) juga mengalami penurunan dan kenaikan harga, dimana pada tahun 2013 harga minyak goreng Malinda mengalami penurunan sebesar 22,14\%. Namun pada tahun 2014 harga minyak goreng Malinda mengalami kenaikan yakni sebesar 9,05\%, tetapi mengalami

Analisis Faktor-Faktor Yang Mempengaruhi Permintaan Konsumen Rumah Tangga Terhadap

Minyak Goreng Curah Di Gampong Lamtimpeung Kecamatan Darussalam Aceh Besar 
penurunan kembali pada tahun 2015 yakni sebesar 9,42\% dan mengalami kenaikan kembali pada tahun 2016 yakni sebesar 31,46\%.

Hal diatas menunjukkan bahwa harga minyak goreng kemasan relatif lebih mahal jika dibandingkan dengan harga minyak goreng curah. Meskipun harga minyak goreng kemasan sempat mengalami penurunan, namun hal itu juga sejalan dengan minyak goreng curah yang juga mengalami penurunan. Sehingga dari tahun ke tahun harga minyak goreng kemasan tetap lebih mahal dari minyak goreng curah.

Dapat dilihat bahwa minyak goreng kemasan memiliki banyak kelebihan jika dibandingkan minyak goreng curah, namun masih ada konsumen rumah tangga yang memilih minyak goreng curah guna memenuhi kebutuhan sehari-hari. Menyikapi hal tersebut, pemerintah telah memperbaharui regulasi tentang minyak goreng di Indonesia Nomor 87/M-IND/PER/12/2013 tentang pemberlakuan Standar Nasional Indonesia (SNI) minyak goreng secara wajib, menjadi Nomer 35/M-IND/PER/3/2015 tentang petunjuk teknis pelaksanaan pemberlakuan Standar Nasional Indonesia (SNI) minyak goreng sawit. Menurut Kementrian Perdagangan, pemerintah menginginkan minyak goreng yang dikonsumsi masyarakat harus memenuhi kriteria kesehatan yang prima. Akan lebih aman bila konsumen di Indonesia menggunakan minyak goreng kelapa sawit kemasan, karena proses produksinya sesuai dengan ketentuan pemerintah.

Pelaksanaan regulasi tersebut terus mengalami penundaan hingga saat ini, dikarenakan masih dibutuhkannya waktu serta kesiapan dalam proses konversi minyak goreng curah menjadi minyak goreng kemasan. Sulitnya pemerintah dalam merangkul usaha kecil yang tersebar di seluruh wilayah Indonesia menjadi kendala tersendiri bagi pemerintah dan banyak konsumen yang merasa keberatan akan kebijakan tersebut, karena kebijakan tersebut dinilai akan memukul usaha kecil serta menyulitkan kalangan rumah tangga tidak mampu (tempo).

Meskipun minyak goreng kemasan dianjurkan oleh pemerintah karena memiliki banyak keunggulan dari pada minyak goreng curah, hal tersebut tidak menghilangkan minat konsumen akan kebutuhannya terhadap minyak goreng curah. Hingga saat ini permintaan konsumen terhadap minyak goreng curah masih ada. Berdasarkan survei pra penelitian yang peneliti lakukan di Gampong Lamtimpeung Kecamatan Darussalam Aceh Besar, 58\% atau 103 konsumen rumah tangga dari 177 konsumen rumah tangga disana masih menggunakan minyak goreng curah. Angka tersebut didapatkan dari hasil survei lapangan sebelum penelitian dilakukan, dikarenakan keterbatasan informasi mengenai jumlah pengguna minyak goreng curah.

Permintaan adalah keinginan konsumen membeli suatu barang pada berbagai tingkat harga selama periode waktu tertentu (Rahardja, 2008). Beberapa faktor yang mempengaruhi permintaan terhadap suatu barang, yaitu: (1) harga barang itu sendiri, (2) harga barang lain yang terkait, (3) tingkat pendapatan per kapita, (4) selera (5) jumlah penduduk, (6) perkiraan harga dimasa mendatang, (7) distribusi pendapatan, dan (8) usaha-usaha produsen meningkatkan penjualan.

Secara lengkap hukum permintaan menyatakan bahwa "jika harga suatu barang naik, maka jumlah barang yang diminta akan turun. Sebaliknya, jika harga suatu barang turun maka jumlah barang yang diminta akan bertambah". Hukum permintaan tersebut akan berlaku dengan asumsi faktor-faktor lain diluar harga harus dianggap konstan (Cateris Paribus). Hal ini merupakan konsep asli dari penemunya yaitu Alfred Marshall (Ahman, 2009).

Analisis Faktor-Faktor Yang Mempengaruhi Permintaan Konsumen Rumah Tangga Terhadap Minyak Goreng Curah Di Gampong Lamtimpeung Kecamatan Darussalam Aceh Besar 148 (Dede Ery Astuty, T. Fauzi , Mustafa Usman) 
Karena regulasi pemerintah untuk mengkonversi minyak goreng curah menjadi minyak goreng kemasan terus mengalami penundaan dikarenakan permintaan terhadap minyak goreng curah masih ada hingga saat ini, maka penulis tertarik untuk melakukan penulisan ilmiah dengan judul "Analisis Faktor-faktor yang Mempengaruhi Permintaan Konsumen Rumah Tangga Terhadap Minyak Goreng Curah di Gampong Lamtimpeung Kecamatan Darussalam, Aceh Besar".

Tujuan dari penelitian ini adalah untuk menganalisis faktor-faktor yang mempengaruhi permintaan konsumen rumah tangga terhadap permintaan minyak goreng curah di gampong Lamtimpeung Kecamatan Darussalam, Aceh Besar dan untuk menganalisis elastisitas permintaan konsumen rumah tangga terhadap minyak goreng curah di gampong Lamtimpeung Kecamatan Darussalam, Aceh Besar.

\section{Lokasi dan Waktu Penelitian}

\section{METODE PENELITIAN}

Penelitian ini dilaksanakan pada tanggal 22 September 2017 sampai dengan 6 Oktober 2017 di Gampong Lamtimpeung Kecamatan Darussalam, Aceh Besar. Daerah penelitian ditentukan secara sengaja sesuai dengan persyaratan yang diperlukan (purposive) dengan pertimbangan bahwa ada konsumen rumah tangga di Gampong Lamtimpeung yang menggunakan minyak goreng curah. Penetapan lokasi penelitian dilakukan setelah melakukan survey pra penelitian di pasar Tungkop, Aceh Besar guna mencari konsumen rumah tangga mana yang paling banyak mengkonsumsi minyak goreng curah.

\section{Objek dan Ruang Lingkup Penelitian}

Objek dalam penelitian ini adalah konsumen rumah tangga yang menggunakan minyak goreng curah di Gampong Lamtimpeung Kecamatan Darussalam, Aceh Besar. Ruang lingkup penelitiian ini dibatasi pada faktor-faktor yang mempengaruhi permintaan konsumen rumah tangga terhadap minyak goreng curah dan elastisitas permintaan minyak goreng curah. Faktor-faktor yang mempengaruhi permintaan minyak goreng curah meliputi harga minyak goreng curah, harga barag lain (minyak goreng kemasan), harga ikan (ikan tongkol), pendapatan konsumen, jumlah anggota keluarga dan tingkat pendidikan. Elastisitas permintaan mencakup elastisitas harga (harga minyak goreng curah), elastisitas silang (harga minyak goreng kemasan) dan elastisits pendapatan (pendapatan konsumen).

\section{Sumber dan Metode Pengumpulan Data}

Jenis data yang digunakan pada penelitian ini terdiri dari data primer dan data sekunder. Data primer yang digunakan yaitu faktor-faktor yang mempengaruhi permintaan minyak goreng curah di gampong Lamtimpeung Kecamatan Darussalam Aceh Besar, sedangkan data sekunder berupa data harga minyak goreng curah daan miyak goreng kemasan kota Banda Aceh tahun 2012 sampai tahun 2016. Metode pengumpulan data primer dilakukan melalui wawancara kepada 51 konsumen rumah tangga minyak goreng curh di gampong Lamtimpeung Kecamatan Darussalam Aceh Besar dengan menggunakan kuisioner penelitian, sedangkan metode pengumpulan data sekunder diperoleh dari Dinas Pangan Provinsi Aceh.

\section{Model Analisis}

\section{Analisis Regresi Linear Berganda}

Menurut (Sudjana, 2002) analisis regresi linear berganda yaitu hubungan secara linear anatara dua atau lebih variabel independen $(\mathrm{X} 1, \mathrm{X} 2, \mathrm{X} 3, \ldots, \mathrm{Xn})$ dengan variabel dependen (Y). Dalam penelitian ini model fungsi permintaan yang digunakan adalah model

Analisis Faktor-Faktor Yang Mempengaruhi Permintaan Konsumen Rumah Tangga Terhadap

Minyak Goreng Curah Di Gampong Lamtimpeung Kecamatan Darussalam Aceh Besar 
regresi berganda yang ditransformasikan kedalam bentuk logaritma natural (LN). Adapun persamaannya sebagai berikut:

$\mathrm{LN} \mathrm{Y} \mathrm{Y}_{\mathrm{i}}=\mathrm{LN} \beta_{0}+\beta_{1} \mathrm{LN} \mathrm{X}+\beta_{2} \mathrm{LN} \mathrm{X}_{2}+\beta_{3} \mathrm{LN} \mathrm{X}{ }_{3}+\beta_{4} \mathrm{LN} \mathrm{X} \mathrm{X}_{4}+\beta_{5} \mathrm{LN} \mathrm{X}{ }_{5}+\beta_{6} \mathrm{LN} \mathrm{X}_{6}+\mathrm{e}_{\mathrm{i}}$

Dimana:

$\mathrm{Y}_{\mathrm{i}} \quad=$ Permintaan minyak goreng curah $(\mathrm{Kg} / \mathrm{bulan})$

$\mathrm{X}_{1} \quad=$ Harga minyak goreng curah $(\mathrm{Rp} / \mathrm{kg})$

$\mathrm{X}_{2} \quad$ = Harga minyak goreng kemasan $(\mathrm{Rp} / \mathrm{kg})$

$\mathrm{X}_{3} \quad=$ Harga ikan $(\mathrm{Rp} / \mathrm{kg})$

$\mathrm{X}_{4} \quad=$ Pendapatan (Rp/bulan)

$\mathrm{X}_{5} \quad$ = Jumlah anggota keluarga (orang)

$\mathrm{X}_{6}=$ Tingkat pendidikan (tahun)

$\beta_{0} \quad=$ Konstanta

$\mathrm{e}_{\mathrm{i}} \quad=$ Error

$\beta_{1}, \ldots, \beta_{5}=$ Koefesien Regresi.

Untuk menguji kebenaran hipotesis yang dirumuskan, maka dilakukan dengan menggunakan pengujian statistik. Adapun uji statistik yang dilakukan pada penelitian ini meliputi Uji t, Uji F , Uji Determinasi dan Uji Asumsi Klasik yang dapat dilihat pada penjelasan sebagai berikut:

a. Uji-F (uji pengaruh secara serempak)

Uji ini untuk mengetahui pengaruh secara serempak antara variabel bebas $\left(\mathrm{X}_{1}, \mathrm{X}_{2}, \mathrm{X}_{3}, \mathrm{D}_{1}, \mathrm{D}_{2}, \mathrm{D}_{3}\right)$ terhadap variabel terikat $(\mathrm{Y})$ pada taraf nyata $(\alpha=0,05)$ diuji dengan menggunakan uji $\mathrm{F}$ dengan menggunakan rumus sebagai berikut:

F-hitung $=\frac{R^{2} / k}{\left(1-R^{2}\right) /(n-k-1)}$ Sudjana (1992)

Dimana:

$\mathrm{R}^{2}=$ koefesien determinasi

$\mathrm{k}=$ jumlah variabel bebas

$\mathrm{n}=$ jumlah sampel

Hipotesis:

Ho : Harga minyak goreng curah, harga minyak gorebg kemasan, harga ikan, pendapatan konsumen, jumlah anggota keluarga dan tingkat pendidikan secara serempak tidak berpengaruh signifikan terhadap permintaan minyak goreng curah di gampong Lamtimpeung Kecamatan Darussalam, Aceh Besar.

Ha : Harga minyak goreng curah, harga minyak gorebg kemasan, harga ikan, pendapatan konsumen, jumlah anggota keluarga dan tingkat pendidikan secara serempak berpengaruh signifikan terhadap permintaan minyak goreng curah di gampong Lamtimpeung Kecamatan Darussalam, Aceh Besar.

b. Uji-t (uji pengaruh secara parsial)

Uji t digunakan untuk mengetahui pengaruh masing-masing variabel bebas (X) terhadap variabel terikat (Y) secara parsial (terpisah). Diuji dengan menggunakan uji t dengan menggunakan rumus sebagai berikut:

$$
\text { t-hitung }=\frac{\left|a_{i}\right|}{S E_{a i}}
$$

Dimana: 
$\mathrm{a}_{\mathrm{i}} \quad=$ koefesien regresi variabel bebas ke-i

$\mathrm{SE}_{\mathrm{ai}}=$ standar error ke- $\mathrm{i}$

Hipotesis:

Ho : Harga minyak goreng curah, harga minyak gorebg kemasan, harga ikan, pendapatan konsumen, jumlah anggota keluarga dan tingkat pendidikan secara parsial tidak berpengaruh signifikan terhadap permintaan minyak goreng curah di gampong Lamtimpeung Kecamatan Darussalam, Aceh Besar.

Ha : Harga minyak goreng curah, harga minyak gorebg kemasan, harga ikan, pendapatan konsumen, jumlah anggota keluarga dan tingkat pendidikan secara parsial berpengaruh signifikan terhadap permintaan minyak goreng curah di gampong Lamtimpeung Kecamatan Darussalam, Aceh Besar.

\section{c. Uji Determinasi $\mathbf{R}^{2}$}

Uji determinasi digunakan untuk mengetahui seberapa besar hubungan dari beberapa variabel dalam pengertian yang lebih jelas. Koefisien determinasi akan menjelaskan seberapa besar perubahan atau variasi suatu variabel bisa dijelaskan oleh perubahan atau variasi pada variabel yang lain (Santoso dan Ashari, 2005:125). Rumus yang digunakan, yaitu:

$$
\mathrm{R}^{2}=\frac{j k_{(r e g)}}{\Sigma y i^{2}}
$$

Dimana:

$\mathrm{jk}_{(\mathrm{reg})}=$ jumlah kuadrat regresi

$\Sigma \mathrm{yi}^{2}=$ jumlah kuadrat total

Penelitian terhadap koefisien determinasi $\left(\mathrm{R}^{2}\right)$ bertujuan untuk mengukur derajat hubungan antara tiga variabel atau lebih. Nilai $R^{2}$ menunjukkan proporsi keragaman total nilai-nilai variabel $\mathrm{Y}$ yang dapat dijelaskan oleh nilai-nilai variabel $\mathrm{X}$. Nilai $\mathrm{R}^{2}$ adalah antar nol dan satu. Nilai $\mathrm{R}^{2}$ yang kecil (nol) menjelaskan bahwa kemampuan satu variabel independen dalam menjelaskan variabel dependen amat terbatas, sedangkan nilai $\mathrm{R}^{2}$ satu berarti variabelvariabel independen memberikan hampir semua informasi yang dibutuhkan untuk memprediksi variabel dependen.

\section{d. Uji asumsi klasik}

Untuk menghindari penyimpangan-penyimpangan spesifikasi model regresi linier berganda, maka akan dideteksi menggunakan uji asumsi klasik. Adapun uji asumsi klasik yang digunakan, yaitu:

1. Uji Normalitas

Uji normalitas adalah pengujian tentang kenormalan distribusi data. Pada analisis parametrik, asumsi yang harus dimiliki oleh data adalah bahwa data tersebut terdistribusi secara normal. Uji normalitas dapat dilakukan dengan uji Kolmogrov Smirnov.

2. Uji Multikolinieritas

Menurut Imam Ghozali (2013), uji multikolinieritas bertujuan untuk menguji apakah dalam model regresi ditemukan adanya korelasi antar variabel-variabel bebas.

3. Uji Autokorelasi 
Autokorelasi merupakan korelasi antara anggota seri observasi yang disusun menurut urutan waktu (data time series) atau urutan tempat (data cross section), atau korelasi yang timbul pada dirinya sendiri.

\section{Elastisitas Permintaan}

Elastisitas permintaan menggambarkan derajat kepekaan fungsi permintaan terhadaap perubahan yang terjadi pada variavel-variabel yang mempengaruhinya. Tiga variabel yang mempengaruhi maka dikenal tiga elastisitas permintaan, yaitu elastisitas harga (barang sendiri), elastisitas silang (terhadap perubahan harga barang lain) dan elastisitas pendapatan (terhadap perubahan pendapatan atau anggaran belanja).

\section{HASIL PENELITIAN DAN PEMBAHASAN}

Untuk menjawab hipotesis I digunakan metode analisis regresi linier berganda yang ditransformasikan kedalam Logaritma Natural (LN) dengan menggunakan SPSS. Adapun hasil uji regresi linier berganda Logaritma Natural (LN) dapat dilihat pada tabel 18 berikut ini:

Tabel 3. Hasil Uji Regresi Linier Berganda Logaritma Natural (LN)

\begin{tabular}{|c|c|c|c|c|c|c|}
\hline \multicolumn{2}{|c|}{ Model } & \multicolumn{2}{|c|}{$\begin{array}{l}\text { Unstandardized } \\
\text { Coefficients }\end{array}$} & \multirow{3}{*}{$\begin{array}{c}\text { Standardized } \\
\text { Coefficients } \\
\text { Beta }\end{array}$} & $\mathrm{t}$ & Sig. \\
\hline & & B & Std. Error & & & \\
\hline 1 & (Constant) & -10.835 & 16.353 & & -.663 & .511 \\
\hline & $\begin{array}{l}\text { Harga minyak } \\
\text { goreng curah }\end{array}$ & -1.997 & 1.292 & .069 & -1.545 & .444 \\
\hline & $\begin{array}{l}\text { Harga minyak } \\
\text { goreng kemasan }\end{array}$ & 3.570 & 1.427 & .013 & 2.502 & .042 \\
\hline & Harga ikan & -.040 & .750 & -.005 & -.054 & .957 \\
\hline & $\begin{array}{l}\text { Pendapatan } \\
\text { Konsumen }\end{array}$ & -.113 & .064 & .178 & -1.767 & .084 \\
\hline & $\begin{array}{l}\text { Jumlah anggota } \\
\text { rumah tangga }\end{array}$ & 2.754 & 1.301 & .751 & 2.116 & .020 \\
\hline & $\begin{array}{l}\text { Tingkat } \\
\text { Pendidikan }\end{array}$ & .074 & .127 & .060 & .583 & .561 \\
\hline
\end{tabular}

Dari hasil perhitungan statistik dengan menggunakan program SPSS seperti yang terlihat pada tabel 3 diatas, maka diperoleh persamaan regresi linier berganda Logaritma Natural (LN) sebagai berikut:

$$
\begin{aligned}
\hat{\operatorname{LnYi}}= & -10,835-1,997 \operatorname{LnX} X_{1 i}+3.570 \operatorname{LnX}_{2 i}-0,040 \operatorname{LnX}_{3 i}-0,113 \operatorname{LnX} X_{4 i}+0,852 \operatorname{LnX} X_{5 i}+ \\
& 0,074 \operatorname{Ln} X_{6 i}
\end{aligned}
$$

Berdasarkan koefisien regresi dari masing-masing variabel bebas pada persamaan regresi diatas, maka dapat dijelaskan sebagai berikut: 
a. Dalam penelitian ini diperoleh nilai konstanta sebesar -10,835. Artinya jika nilai $X_{1}$, $\mathrm{X}_{2}, \mathrm{X}_{3}, \mathrm{X}_{4}, \mathrm{X}_{5}, \mathrm{X}_{6}$ dianggap nol atau konstan, maka akan menurunkan permintaan minyak goreng curah sebanyak $10,835 \mathrm{~kg}$.

b. Nilai koefisien regresi harga minyak goreng curah $\left(\mathrm{X}_{1}\right)$ yang didapatkan adalah sebesar -1,997, artinya setiap peningkatan harga minyak goreng curah sebesar Rp $1 / \mathrm{kg}$ maka akan menurunkan permintaan minyak goreng curah sebanyak $1,997 \mathrm{~kg}$.

c. regresi harga minyak goreng kemasan $\left(\mathrm{X}_{2}\right)$ yang didapatkan sebesar 3,570, artinya setiap peningkatan harga minyak goreng kemasan sebesar $\mathrm{Rp} 1 / \mathrm{kg}$ maka akan meningkatkan permintaan minyak goreng curah sebanyak $3,570 \mathrm{~kg}$.

d. Nilai koefisien regresi harga ikan $\left(\mathrm{X}_{3}\right)$ didapatkan nilai sebesar -0,040, artinya setiap peningkatan harga ikan sebesar Rp 1/kg maka akan menurunkan permintaan minyak goreng curah sebanyak $0,040 \mathrm{~kg}$.

e. Nilai koefisien regresi pendapatan konsumen $\left(\mathrm{X}_{4}\right)$ yang didapatkan sebesar $-0,113$, artinya setiap peningkatan pendapatan sebesar Rp 1/bulan maka akan menurunkan permintaan minyak goreng curah sebanyak $0,113 \mathrm{~kg}$.

f. Nilai koefisien regresi jumlah anggota keluarga $\left(\mathrm{X}_{5}\right)$ didapatkan nilai sebesar 0,852 , artinya setiap penambahan 1 orang anggota keluarga maka akan meningkatkan permintaan minyak goreng curah sebesar $0,852 \mathrm{~kg}$.

g. Nilai koefisien regresi tingkat pendidikan $\left(\mathrm{X}_{6}\right)$ didapatkan nilai sebesar 0,074 , artinya setiap penambahan 1 tahun tingkat pendidikan maka akan meningkatkan permintaan minyak goreng curah sebesar $0,074 \mathrm{~kg}$.

\section{Pengujian Hipotesis secara Serempak (Uji F)}

Pembuktian hipotesis secara simultan dapat dilihat pada tabel 5 sebagai berikut:

Tabel 5. Hasil Uji F

\begin{tabular}{llrrrrr}
\hline \multicolumn{1}{l}{ Model } & \multicolumn{1}{c}{ Sum of } & Df & Mean Square & F & \multicolumn{1}{c}{ Sig. } \\
& & Squares & & & & \\
1 & Regression & 1.988 & 6 & .331 & 16.926 & $.000^{\mathrm{a}}$ \\
& Residual & .861 & 44 & .020 & & \\
\multicolumn{1}{l}{ Total } & 2.849 & 50 & & & \\
\hline
\end{tabular}

Sumber: Data Primer, 2017 (diolah)

Dari hasil analisis regresi linier berganda diperoleh nilai $\mathrm{F}$ hitung sebesar 16,926 pada batasan signifikansi 0,000 atau $<0,05$. Sedangkan nilai $F$ tabel pada taraf signifikansi 5\% adalah sebesar 2,42. Dengan demikian $F$ hitung $(16,926)$ diperoleh $>\mathrm{F}$ tabel $(2,42)$, sehingga dapat diambil suatu keputusan bahwa hipotesis alternatif $\left(\mathrm{H}_{\mathrm{a}}\right)$ diterima dan menolak hipotesis nol $\left(\mathrm{H}_{0}\right)$.

Sehingga dari keputusan diatas dapat pula ditarik kesimpulan bahwa harga minyak goreng curah, harga minyak goreng kemasan, harga ikan, pendapatan konsumen, jumlah anggota rumah tangga dan tingkat pendidikan secara serempak berpengaruh signifikan terhadap permintaan minyak goreng curah di Gampomg Lamtimpeung Kecamatan Darussalam, Aceh Besar.

\section{Pengujian Hipotesis secara Parsial (Uji t)}

Penjelasan mengenai pengaruh masing-masing variabel bebas terhadap permintaan minyak goreng curah di gampong Lamtimpeung Kecamatan Darussalam Aceh Besar adalah sebagai berikut:

Analisis Faktor-Faktor Yang Mempengaruhi Permintaan Konsumen Rumah Tangga Terhadap 
a. Harga minyak goreng curah $\left(\mathrm{X}_{1}\right)$

Dari hasil output spss diperoleh nilai t hitung untuk variabel harga minyak goreng curah sebesar -1,545 pada batasan nilai signifikansi 0,444. Sementara nilai t tabel pada tingkat kesalahan 5\% adalah 2,015. Dengan demikian nilai $t_{\text {hitung }}<\mathrm{t}_{\text {tabel }}$, sehingga harga minyak goreng curah secara parsial tidak berpengaruh signifikan terhadap permintaan minyak goreng curah.

b. Harga minyak goreng kemasan $\left(\mathrm{X}_{2}\right)$

Dari hasil output spss diperoleh nilai t hitung untuk variabel harga minyak goreng kemasan sebesar 2,502 pada batasan nilai signifikansi 0,042 . Sementara nilai t tabel pada tingkat kesalahan 5\% adalah 2,015. Dengan demikian nilai $t_{\text {hitung }}>t_{\text {tabel }}$, sehingga harga minyak goreng kemasan secara parsial berpengaruh signifikan terhadap permintaan minyak goreng curah.

c. Harga ikan $\left(\mathrm{X}_{3}\right)$

Dari hasil output spss diperoleh nilai thitung untuk variabel harga ikan adalah sebesar -0,054 pada batasan nilai signifikansi 0,957. Sementara nilai t tabel pada tingkat kesalahan 5\% adalah 2,015. Dengan demikian nilai $t_{\text {hitung }}<t_{\text {tabel}}$, sehingga harga ikan secara parsial tidak berpengaruh signifikan terhadap permintaan minyak goreng curah.

d. Pendapatan Ruamh Tangga Konsumen $\left(\mathrm{X}_{4}\right)$

Dari hasil output spss diperoleh nilai t hitung untuk variabel pendapatan konsumen sebesar -1.767 pada batasan nilai signifikansi 0,084. Sementara nilai t tabel pada tingkat kesalahan 5\% adalah 2,015. Dengan demikian nilai $t_{\text {hitung }}<t_{\text {tabel }}$, sehingga pendapatan konsumen secara parsial tidak berpengaruh signifikan terhadap permintan minyak goreng curah.

e. Jumlah anggota rumah tangga $\left(\mathrm{X}_{5}\right)$

Dari hasil output spss diperoleh nilai t hitung untuk variabel jumlah anggota keluarga sebesar 2,116 pada batasan nilai signifikansi 0,020. Sementara nilai t tabel pada tingkat kesalahan 5\% adalah 2,015. Dengan demikian nilai $t_{\text {hitung }}>t_{\text {tabel, }}$, sehingga jumlah anggota rumah tangga secara parsial berpengaruh signifikan terhadap permintaan minyak goreng curah.

f. Tingkat pendidikan $\left(\mathrm{X}_{6}\right)$

Dari hasil output spss diperoleh nilai t hitung untuk variabel tingkat pendidikan sebesar 0,583 pada batasan nilai signifikansi 0,561 . Sementara nilai t tabel pada tingkat kesalahan 5\% adalah 2,015. Dengan demikian nilai $t_{\text {hitung }}<t_{t a b e l}$, sehingga tingkat pendidikan secara parsial tidak berpengaruh signifikan terhadap permintaan minyak goreng curah.

\section{Pengujian Koefisien Determinasi $\left(\mathbf{R}^{2}\right)$}

Hasil output spss hubungan variabel bebas dengan variabel terikat dapat dilihat pada tabel 6 berikut ini: 
Tabel 6. Hasil Analisis Koefisien Determinasi $\left(\mathrm{R}^{2}\right)$

\begin{tabular}{lrrrr}
\hline Model & $\mathrm{R}$ & $\mathrm{R}$ Square & Adjusted R Square & \multicolumn{2}{c}{ Std. Error of the Estimate } \\
1 & $.835^{\mathrm{a}}$ & .698 & .656 & .13991 \\
\hline Sumber: Data primer, & 2017(diolah) & &
\end{tabular}

Berdasarkan hasil analisis diperoleh nilai koefisien korelasi (R) sebesar 0,835. Artinya terdapat hubungan yang positif antara harga minyak goreng curah $\left(\mathrm{X}_{1}\right)$, harga minyak goreng kemasan $\left(\mathrm{X}_{2}\right)$, harga ikan $\left(\mathrm{X}_{3}\right)$, pendapatan konsumen $\left(\mathrm{X}_{4}\right)$, jumlah anggota keluarga $\left(\mathrm{X}_{5}\right)$, dan tingkat pendidikan $\left(\mathrm{X}_{6}\right)$ dengan permintaan minyak goreng curah di Gampong Lamtimpeung Kecamatan Darussalam, Aceh Besar.

Sedangkan nilai koefisien determinasi $\left(\mathrm{R}^{2}\right)$ sebesar 0,698. Hal ini berarti bahwa permintaan minyak goreng curah di Gampong Lamtimpeung Kecamatan Darussalam Aceh Besar (Y) sebesar 69,8\% dapat dijelaskan oleh variabel bebas yang digunakan dalam model yaitu harga minyak goreng curah, harga minyak goreng kemasan, harga ikan, pendapatan konsumen, jumlah anggota keluarga dan tingkat pendidikan. Sementara selebihnya 30,2 \% dijelaskan oleh variabel lainnya yang tidak dirumuskan dalam model penelitian ini.

\section{Elastisitas Permintaan}

Untuk mengetahui nilai elastisitas dari masing-masing variabel yang mempengaruhi permintaan minyak goreng curah dapat diketahui dari nilai koefisien regresi masing-masing variabel penduganya. Karena salah satu ciri dari model regresi berganda Logaritma Natural (LN) adalah nilai koefisien regresi dapat menunjukkan nilai elastisitasnya. Berikut ini adalah penjelasan elastisitas permintaan minyak goreng curah, yang dapat dilihat pada tabel berikut ini:

Tabel 7. Nilai Elastisitas Permintaan Minyak Goreng Curah di Gampong Lamtimpeung Kecamatan Darussalam, Aceh Besar

\begin{tabular}{llrl}
\hline Variabel & \multicolumn{2}{l}{ Nilai Elastisitas } & \\
\cline { 2 - 4 } & Harga & Silang & Pendapatan \\
\hline Harga Minyak Goreng Curah $\left(\mathrm{X}_{1}\right)$ & $-1,997$ & & \\
Harga Minyak Goreng Kemasan $\left(\mathrm{X}_{2}\right)$ & & 3,570 & \\
Harga Ikan Tongkol $\left(\mathrm{X}_{3}\right)$ & & -0.040 & \\
Pendapatan per Bulan $\left(\mathrm{X}_{4}\right)$ & & & $-0,113$ \\
\hline
\end{tabular}

Sumber: Data Primer, 2017 (diolah)

Dari tabel 7 diatas dapat dilihat bahwa nilai elastisitas permintaan harga minyak goreng curah di gampong Lamtimpeung kecamatan Darussalam Aceh Besar adalah -1,997. Sedangkan nilai elastisitas silang harga minyak goreng kemasan di gampong Lamtimpeung adalah senilai 3,570 dengan nilai elastisitas harga ikan tongkol sebesar -0,040 dan nilai elastisitas pendapatan konsumen rumah tangga di gampong Lamtimpeung kecamatan Darussalam Aceh Besar adalah senilai -0,113.

Dapat diambil kesimpulan bahwa nilai koefisien elastisitas harga tersebut menunjukkan bahwa minyak goreng curah bersifat inelastis, karena nilai koefisien elastisitas harga $<1$. Elastisitas silang memiliki nilai sebesar 3,570 (elastisitas harga minyak goreng kemasan) dan -0.040 (elastisitas harga ikan tongkol). Karena nilai elastisitas silang bernilai positif untuk minyak goreng kemasan sehingga minyak goreng kemasan merupakan barang subtitusi dari minyak goreng curah. Sedangkan nilai elastisitas silang bernilai negatif untuk ikan tngkol sehingga ikan tongkol merupakan barang komplementer dan elastisitas

Analisis Faktor-Faktor Yang Mempengaruhi Permintaan Konsumen Rumah Tangga Terhadap

Minyak Goreng Curah Di Gampong Lamtimpeung Kecamatan Darussalam Aceh Besar 
pendapatan menunjukkan bahwa nilainya berada lebih kecil dari 1 yakni $-0,113$ serta bertanda negatif, berarti minyak goreng curah termasuk barang inferior.

\section{SIMPULAN DAN SARAN}

Secara parsial variabel harga minyak goreng kemasan dan jumlah anggota keluarga berpengaruh signifikan terhadap permintaan minyak goreng curah di Gampong Lamtimpeung Kecamatan Darussalam, Aceh Besar sedangkan harga minyak goreng curah, harga ikan tongkol, pendapatan konsumen, jumlah anggota keluarga dan tingkat pendidikan secara parsial tidak berpengaruh signifikan terhadap permintaan minyak goreng curah di gampong Lamtimpeung Kecamatan Darussalam, Aceh Besar. Elastisitas harga terhadap permintaan minyak goreng curah bernilai -1,997 yang berarti inelastis, elastisitas silang menunjukkan minyak goreng kemasan merupakan barang subtitusi dari minyak goreng curah karena nilainya positif yakni 3,570 dan ikan tongkol merupakan barang komplementer karena nillainya negatif yakni sebesar -0.040 serta elastisitas pendapatan bernilai $-0,113$ yang menunjukkan bahwa nilainya lebih kecil dari satu dan bertanda negatif, berarti minyak goreng curah termasuk barang inferior.

Melihat dari hasil elastisitas disarankan kepada pedagang minyak goreng curah agar menjual minyak goreng kemasan juga, karena nilai elastisitas pendapatan menunjukkan bahwa minyak goreng curah merupakan barang inferior. Disarankan pada rumah tangga yang berpendapatan relatif tinggi sebaiknya lebih selektif dan cermat lagi dalam memilih minyak goreng. Sebaiknya konsumen rumah tangga memilih minyak goreng kemasan dibandingkan minyak goreng curah, mengingat harga diantara keduanya yang tidak jauh berbeda namun minyak goreng kemasan memiliki kualitas yang lebih prima dibandingkan minyak goreng curah. Diharapkan kepada pemerintah agar dapat merangkul pihak yang terlibat dalam peredaran minyak goreng curah, agar pengkonversian dari minyak goreng curah ke minyak goreng kemasan dapat segera tercapai.

\section{DAFTAR PUSTAKA}

Ahman., Eeng dan R. Yana. 2009. Teori Ekonomi Mikro. Universitas Pendidikan Indonesia. Bandung.

Amang, B., Pantjar. S., dan Anas. R., 1996. Ekonomi Minyak Goreng di Indonesia. IPB Press. Bogor.

Amirullah., 2002. Perilaku Konsumen. Cetakan Pertama. Penerbit: Graha Ilmu. Jakarta.

Arsyad, L., 1991. Pengantar Perencanaan dan Pembangunan Ekonomi Daerah. Edisi Pertama. BPFE. Yogyakarta.

Arsyad, A., 1996. Media Pembelajaran. PT Raja Grafindo Persada. Jakarta. 
Asmidah. 2013. Faktor-faktor yang mempengaruhi permintaan dan penawaran jeruk manis di pasar tradisional kota Medan provinsi Sumatera Utara. Skripsi. Fakultas Pertanian. Universitas Sumatera Utara. Medan.

Case, K.L. \& Fair, R.C., 2005. Prinsip-prinsip Ekonomi Mikro. Edisi 7. Indeks Kelompok Gramedia. Jakarta.

Daniel, M., 2002. Pengantar Ekonomi Pertanian. Bumi Aksara. Jakarta.

Ghozali, I., 2013. Aplikasi Analisis Multivariate dengan program SPSS. Edisi Ketujuh. Badan Penerbit Universitas Diponegoro. Semarang.

GIMNI, 2014 dalam Utami 2014. Konversi Minyak Goreng Curah ke Kemasan Sederhana. Pusdiklat Perdagangan. Kementerian Perdagangan. Jakarta.

Hanafie, R., 2010. Pengantar Ekonomi Pertanian. ANDI Yogyakarta. Yogyakarta.

Hikmawati, K. A., Z. Arifin., dan K. Hidayat. 2016. Pengaruh karakteristik konsumen terhadap keputusan pembelian. Jurnal Administrasi Bisnis (JAB). 37 (2) : 11.

Ikasari, D.M., P. Deoranto., R. Lutfian., dan R. Silalahi. 2016. Analisis faktor-faktor yang mempengaruhi perilaku konsumen dalam pengambilan keputusan pembelian beras organik. Jurnal Teknologi Pertanian. Universitas Brawijaya. 17 (1) : 69 78 .

Joesron, Tati Suharti, Fathorrozi. 2003. Teori Ekonomi Mikro. Penerbit Salemba Empat. Jakarta.

Ketaren, S., 1986. Pengantar Teknologi Minyak dan Lemak Pangan. Cetakan Pertama. UIPress. Jakarta.

Kotler, P. \& Armstrong., 2008. Prinsip-Prinsip Pemasaran 1. Edisi keduabelas. Erlangga. Jakarta.

Kurniawati, F. 2016. Analisis faktor yang menjadi keputusan konsumen dalam membeli sepeda motor Honda Beat 110cc. Skripsi. Fakultas Ekonomi. Universitas Darma Persada. Jakarta.

Mantra, I. B. 2003. Demografi Umum. Pustaka Raja. Jakarta.

Manurung, Mandala dan Prathama Rahardja. 2004. Uang, Perbankan, dan Ekonomi Moneter. Penerbit Fakultas Ekonomi Universitas Indonesia. Jakarta.

Martianto, D. 2005. Pengembangan Diversifikasi Konsumsi Pangan. Seminar Pengembangan Diversifikasi Pangan. 21 Oktober. Bappenas. Jakarta. 
Matital, G., W. B. Parera. 2013. Analisis faktor-faktor yang mempengaruhi perilaku konsumen dalam pembelian produk olahan sagu. Jurnal Agribisnis Kepulauan. Universitas Pattimura. 1 (3) : 68-80.

Mustafid dan Aan Gunawan. 2008. Pengaruh atribut produk terhadap keputusan pembelian kripik pisang "Kenali" pada PD. Asa Wira Perkasa di Bandar Lampung. Jurnal Bisnis dan Manajemen. 4 (2) : 123-140.

Nasution, A. N. 2009. Faktor-faktor yang mempengaruhi permintaan rumah tangga terhadap sayuran organik di kota Bogor, Jawa Barat. Skripsi. Fakultas Ekonomi dan Manajemen. IPB. Bogor.

Pracoyo, A. 2006. Aspek Dasar Ekonomi Mikro. PT. Gramedia Widiasarana Indonesia. Jakarta.

Pratama Rahardja dan Mandala Manurung, 2008. Teori Ekonomi Makro: Suatu Pengantar. Lembaga Penerbit FE UI. Jakarta.

Priyanti, D. 2012. Analisis Perilaku Permintaan Rumah Tangga dan Jumlah Pasokan Cabai Merah Keriting di DKI Jakarta. Skripsi. Institut Pertanian Bogor. Bogor.

Putri, M., S., M. B. Darus dan S. N. Lubis. 2014. Analisis faktor-faktor yang mempengaruhi konsumsi gula pasir curah dan proses keputusan pembelian konsumen gula pasir curah di kota Medan. Jurnal Sosial Ekonomi Pertanian dan Agribisnis. Fakultas Pertanian. Universitas Sumatera Utara. Medan. 3 (3).

Putry, A., B. S. Priyono dan M. Suryanty. 2017. Faktor-faktor yang Mempengaruhi Tingkat Pembelian Minyak Goreng Curah pada Rumah Tanga di Kota Bengkulu. Jurnal AGRISEP. Fakultas Pertanian. Universitas Bengkulu. Bengkulu. 16 (1).

Ria Tetra Valencia S. 2013. Analisa Permintaan Bawang Merah Lokal di Kota Banda Aceh. Skripsi. Fakultas Pertanian. Universitas Syiah Kuala. Banda Aceh.

Sadono, S., 2003. Pengantar Teori Mikroekonomi. Raja Grafindo Persada. Jakarta.

Samosir, H. V. 2008. Faktor-faktor yang mempengaruhi perilaku konsumen terhadap permintaan telur ayam kampung. Skripsi. Fakultas Pertanian. Universitas Sumatera Utara. Medan.

Shavana, B. D., M. B. Darus dan S. N. Lubis. 2014. Faktor-faktor yang mempengaruhi permintaan dan penawaran minyak goreng curah di kota Medan. Skripsi. Fakultas Pertanian. USU. Medan.

Simatupang dan Purwoto, 2005. Ekonomi Minyak Goreng di Indonesia. PB Press. Bogor.

Sugiyono. 2008. Metode Penelitian Kunatitatif Kualitatif dan $R \& D$. Bandung Alfabeta. Bandung. 
Tempo.co. 31 Januari, 2016. Minyak Goreng Curah Dilarang, Apa Dampaknya ke Pedangang?,(http://bisnis.tempo.co/read/740978/minyak-goreng-curah-dilarangapa-dampaknya-ke-pedagang), diakses 12 Oktober 2017.

Todaro, M., 2000. Pembangunan Ekonomi di Dunia Ketiga. Edisi Ketujuh Jilid I. Erlangga. Jakarta.

Umar, H., 2000. Riset Pemasaran dan Prilaku Konsumen. Jakarta. Gramedia Pustaka Utama: Jakarta.

Widayat, Suherman dan K Haryani. 2006. Optimasi proses adsorbsi minyak goreng bekas dengan adsorbent zeolit alam: studi sengurangan bilangan asam. Jurnal Teknik GELAGAR. 17 (1).

Zikmund, W. G. 1997. Business Research Methods. Fifth Edition. The Dryden Press Harcourt Brace College Publishers. New York. 